\title{
Antonio Manuel Hespanha, in memoriam
}

\author{
Maria Inés Carzolio
}

Hace unos meses, como suelo hacer cuando tengo tiempo para ello, envié saludos y buenos deseos a los investigadores que conozco y admiro. Entre ellos, naturalmente al Dr. Antonio Manuel Hespanha. Aunque mis saludos suelen ser someros -solo para recordar a los destinatarios que los tengo bien presentes en mi memoria y que los aprecio- en esta ocasión mi mensaje fue más largo y me detuve en hacerle saber lo importante que había sido para mí el hecho de haber conocido sus investigaciones. No sabía yo de su enfermedad. Me respondió de manera afectuosa y muy amable -siempre lo era- y me retribuyó los buenos deseos. Lejos estaba yo de saber acerca de su estado de salud, aunque siempre que viajaba al continente americano me enviaba un mensaje, abierto siempre a la posibilidad de ofrecer algún curso en la Argentina.

La lectura de otros historiadores de la nueva historia politica, como Pablo Fernández Albaladejo y sus artículos reunidos en Fragmentos de Monarquía, así como Cittadinanza de Pietro Costa o Le Portugal au temps du Comte-Duc D'Olivares (1621-1640) de Jean- Fréderic Schaub y las obras de historiadores del derecho como Bartolomé Clavero, en artículos como "Institución política y derecho: acerca del concepto historiográfico de 'Estado Moderno'” o su libro Antidora, me habían abierto un camino hacia la lectura de sus obras. El trayecto por el cual éstas llegan a la Argentina, es aleatorio y no coincide siempre con el momento de su publicación.

Sea como fuere, Las Visperas de Leviatán. Instituciones y poder político. Portugal, siglo XVII (Madrid, Taurus, 1990) donde deslumbra la diafanidad de su discurso, cobró difusión en nuestro país a partir de los años 90. Su rechazo de la idea de continuidad de los conceptos, de las clasificaciones, de los principios jurídicos que él ejemplificaba en el movimiento de los Annales, de una genealogía entre el derecho histórico y el derecho del presente como el instrumento para la naturalización del derecho, de los modelos establecidos de poder, de un derecho natural, de una organización política racional, la del Estado liberal del siglo XIX, fundados en la idea esencialista de un espíritu humano transtemporal que relaciona a los juristas del pasado con los del presente. Denunció el carácter ilusorio de las aparentes continuidades terminológicas que derivaban de la ilegitimidad de aplicar, en el trabajo histórico, las categorías jurídicas actuales, procedimiento que solo conducía al anacronismo, ya presente en la crítica de los trabajos pioneros de Otto Brunner, Emile Lousse y Otto V. Gierke. Los protagonistas de la construcción ideológica habían sido el estado liberal representativo y su derecho legislado.

El mensaje era claro: el pasado debía ser leído respetando su alteridad. Tal convicción se desplegó en un programa de extraordinaria riqueza en su artículo "Una nueva historia política e institucional", publicado en Revista Mexicana de Ciencias Politicas y Sociales (vol. 41, No 166, 1996). En ese artículo repasa las características del antiguo régimen, tales como la existencia en él de un universo político plural, de la diversidad de sus niveles de normatividad social, así como la multiplicidad de los instrumentos, procedimientos y recursos mediante los cuales se lograba la aceptación voluntaria o no de las normas, que el imaginario político liberal y su ideología estatalista borraban de la historia al tener en cuenta solamente el nivel estatal del poder y el nivel oficial del derecho.

No cabe duda acerca de la trascendencia que tuvo en la historiografía del estado y del poder su recuperación de la vigencia de la imagen antropomórfica y policéntrica tardomedieval con la cual se representaba la 
coexistencia de diferentes centros autónomos de poder, así como la validez y eficacia, en la temprana modernidad, de la idea de la sociedad como un cuerpo cuyos diferentes órganos, como los diversos órganos sociales, podían poseer la autonomía de funcionamiento precisa para el cumplimiento de las funciones que les estaba atribuida en la economía del todo.

Sus preocupaciones abarcaron un espectro amplísimo tanto de la historia como de la historia del derecho y de problemas del pasado y del presente, que podían ser prácticos ("Un bloco de notas para o trábalho do dia a dia”, Penélope, No 3, 1989 con la aplicación de la informática a la investigación histórica) o teóricos ("Categorías. Una reflexao sobre a prática de clasificar", Análise Social, vol. 38, No 168, 2003), que a veces asumían la forma de una obra unitaria, como la História das Instituiçóes. Épocas medieval e moderna (Coimbra, Almedina, 1982) o de compilaciones, como La Gracia del Derecho. Economía de la Cultura en la Edad Moderna (Centro de Estudios Constitucionales, Madrid, 1993), así también como innumerables colaboraciones en libros colectivos y revistas especializadas. Asimismo fundó - según creo - y dirigió la revista de Historia y Ciencias Sociales, Penélope, cuyo subtítulo Fazer e desfazer a História, fue bien expresivo acerca de los propósitos críticos que la guiaban.

Viajó por todos los continentes impartiendo cursos, seminarios y conferencias, que lo hicieron recalar en América del Sur y en Argentina. Tuvo el reconocimiento de muchos y muy destacados discípulos, a quienes trató de transmitir su "uso de una mirada crítica para volver sobre textos y expresiones a la vista de todos, recorrer con atención caminos cientos de veces transitados cuestionando silencios historiográficos o todo aquello que se daba por supuesto", otro modo de mirar, según aprecia David Martín Marcos ("La otra mirada de Antonio Manuel Hespanha (1945-2019), in memoriam”, Espacio Tiempo y Forma, Serie 4, Historia Moderna, 32, 2019). En eso fue siempre gentil, generoso e incansable.

María Inés Carzolio 